\title{
Guidelines for the Stable Development of Public Bus Transport in the City of Sofia
}

\author{
Svetla Tzvetkova* \\ University of National and World Economy, Sofia, Bulgaria
}

\begin{abstract}
The stable development of public bus transport includes the improvement of the social, economic and ecological aspects of its activity or increasing its social effectiveness through improving the quality of offered transport services, reducing energy consumption, using energy sources more effectively and reducing the harmful effects on the environment. Public bus transport is the most commonly used type of ground transport in the city of Sofia; in recent years, unfortunately, the quality of its services has dropped and its harmful influence on the environment has grown. This is primarily caused by obsolete vehicles and the lack of adequate measures for improving its social and economic effectiveness. The present article substantiates the necessity for its future stable development and outlines the measures for improving the quality of the transport services it offers as well as reducing harmful emissions. In order to support the study's topicality, it should also be pointed out that similar goals and objectives set in the Declaration for reducing harmful emissions, creating conditions for the use of renewable energy and attracting green investments, which Sofia joined during the World Conference for Climate Change held in Paris in December 2015.
\end{abstract}

\section{Introduction}

The stable development of mass public transport is in accordance with the main guidelines of the EU's transport policy for achieving stable urban mobility of the population. It involves encouraging the use of all transport vehicles and combining public transport with various types of individual transport. Urban mobility needs to guarantee the economic development of cities, high quality of life for its residents and environmental protection. Special attention should be given to the problems regarding the provision of high-quality and more accessible urban transport for people with limited mobility, people with disabilities, elderly people and children Like the majority of European cities, Bulgaria's capital also faces the challenge of resolving these issues. It is necessary to adopt urgent measures which involve reduction of traffic jams, improved traffic safety, replacement of obsolete infrastructure, as well as reduction of the harmful influence of urban traffic on the environment - ecological and noise pollution [1].

In recent years most cities in Western Europe have clearly stated their determination to reduce their negative influence on the environment by joining the European Commission's initiative launched in January 2008, which requires ruling classes in cities to commit to the reduction of carbon emissions with $20 \%$ by 2020 . This has also encouraged the creation of a plan containing the measures that cities could adopt to reduce carbon emissions and guarantee a better future. Of course, ecological situations in different cities vary, but several positive trends have already become evident. In about 30 European cities the $\mathrm{CO}_{2}$ emissions per capita are lower than the average value for the EU. Moreover, in recent years citizens have definitely become more conscious about the importance of environmental protection and green goals. This is partially caused by the increased volume of European legislation in the environmental field. However, even an environmentally conscious Europe is still plagued by problems. In most cities, including Sofia, one in three residents go to work by car, thus increasing $\mathrm{CO}_{2}$ emissions and contributing to the overall air pollution. The average share of consumed energy from renewable sources is barely $7,3 \%$, which is far from the EU's goal of increasing the share of this type of energy by 2020 [2].

Bus transport in Sofia is the primary and most preferred means of ground transportation. It, along with personal automobiles, is the primary air pollutant in the capital with harmful emissions and noise pollution. This is primarily caused by the unsatisfactory condition and high average age of the rolling stock, as well as the large number of vehicles that have not been adapted to the social standards for accessibility and have a negative influence on the environment. On the whole, the indicators that characterize the quality of the capital's bus transport are extremely unsatisfactory, which puts the necessity to adopt measures for its stable improvement on the agenda [3].

\section{Analyzing the Mobile Situation in the City of Sofia and the Ecological Condition of "Metropolitan Motor Transport" SJSC}


In 2017 the capital's public transport has registered approximately 500000000 travels, the buses have transported the most passengers $-45 \%$ of the total amount of carried out freights. Subways have transported about $35 \%$, trams $-13 \%$ and $7 \%$ of the passengers have been transported by trolleys (see fig. 1).



Fig. 1. Freights carried out with various types of public transport in 2017

Source: The National Statistics Institute

The buses are the primary and most preferred method of transportation by the capital's citizens. Annually the amount of passenger transports by bus in the capital reaches about 250 million [4].

Services for passenger freights via bus transport within Sofia Municipality are supplied on the basis of contracts for providing public services between "Metropolitan Motor Transport" SJSC and three more bus operators: "Karat-S" JSC, "Union Ivkoni" Ltd. and "Eridantrans" Ltd. "Metropolitan Motor Transport" SJSC is an association with $100 \%$ municipal property, providing public transport services with buses. It services a total of 64 lines - 35 urban and 27 suburban. By the end of 2017, "Metropolitan Motor Transport" SJSC's bus park is comprised of a total of 466 buses, 211 of which are 18-meter and 255 are 12-meter; however, only 340 of them have low floors. The average age of the entire bus park is 11 years. It should also be taken into account that up until 1989, the bus park was annually renewed with an average of about $10-15 \%$, after which no new buses were delivered for many years. During the 19922002 period many depreciated buses were replaced with second-hand 12 to 14-year-old buses, i.e. buses with really poor operational features in terms of expenses for their maintenance. In 2005101 single buses with EURO 3 indicators were delivered; in 2008 - 35 EURO 4 buses and 8 EURO 5 buses which work only with natural gas. In 2015 126 EURO 6 articulated low-floor buses working with natural gas were delivered, financed along the lines of Operational Program "Environment". It is crucial to note that 292 buses from the urban bus park are 12 years old, which is the permissible norm of urban buses' mileage life. On one hand, this stipulates large fixed costs for their operational maintenance and the necessity to maintain a significant number of spare buses to avoid the disruption of the freight rhythm.
In 2013 the EURO VI standard was introduced, imposing strict limitations on two types of emissions in the atmosphere as a result of the functioning of bus transport - nitrous oxides (NO) and solid particulate matter (PM10) [5].

According to Appendix I to Regulation № 595/2009 of the European Parliament and the Council from June 182009 for the approval of the type of motor vehicles and engines in regard to emissions from heavy EURO VI vehicles, the limit values of diesel and gas engine emissions are as follows (see table 1).

Table 1. Limit values of emissions under EURO VI

\begin{tabular}{|l|c|c|l|l|}
\hline \multicolumn{5}{|c|}{ Limit values of emissions under EURO VI } \\
\hline & $\begin{array}{l}\mathrm{CO} \\
\mathrm{mg} / \\
\mathrm{kWh}\end{array}$ & $\begin{array}{l}\mathrm{NO} \\
\mathrm{mg} / \\
\mathrm{kWh}\end{array}$ & $\begin{array}{l}\text { Particulate } \\
\text { matter } \\
\text { mass mg/ } \\
\mathrm{kWh}\end{array}$ & $\begin{array}{l}\text { Number } \\
\text { of } \\
\text { particulate } \\
\text { matter } \\
\# / \mathrm{kWh}\end{array}$ \\
\hline $\begin{array}{l}\text { WHSC } \\
\text { (CI) }\end{array}$ & 1500 & 400 & 10 & $8,0 \times \mathrm{U}^{\mathrm{L}} 11$ \\
\hline $\begin{array}{l}\text { WHTC } \\
\text { (CI) }\end{array}$ & 4000 & 460 & 10 & $6,0 \times \mathrm{U}^{\mathrm{L}} 11$ \\
\hline $\begin{array}{l}\text { WHTC } \\
\text { (PI) }\end{array}$ & 4000 & 460 & 10 & $6,0 \times \mathrm{U}^{\mathrm{L}} 11$ \\
\hline
\end{tabular}

Source: The National Statistics Institute

Where:

WHSC - the cycle of vehicle control in stabilized mode

WHTC - the cycle of vehicle control in transit mode

CI - with compression ignition (diesel)

$\mathrm{PI}$ - with positive ignition (CNG)

As the table clearly indicates, the limit values of emissions under the EURO VI standard are similar for both types of fuel (diesel and CNG).

The next two tables (table 2 and table 3 ) present calculations on the harmful impact (CO and NO emissions) of part of "Metropolitan Motor Transport" SJSC's bus fleet which correspond to the EURO 0, EURO I and EURO II standards.

Table 2. Harmful carbon oxide emissions (CO)

\begin{tabular}{|l|l|l|l|l|l|}
\hline \multicolumn{5}{|c|}{$\begin{array}{l}\text { Calculated carbon } \\
\text { emissions (CO) }\end{array}$} & oxide \\
\hline & & Year & $\begin{array}{l}\text { Type } \\
\text { of fuel }\end{array}$ & $\begin{array}{l}\text { Euro } \\
\text { stand }\end{array}$ & $\begin{array}{l}\text { Total } \\
\mathrm{kg} / \\
\text { year }\end{array}$ \\
\hline $\begin{array}{l}\text { MAN } \\
\text { SL200 }\end{array}$ & 3 & 1976 & Diesel & Euro 0 & $\begin{array}{l}477 \\
394\end{array}$ \\
\hline $\begin{array}{l}\text { Mercedes } \\
\text { 0305 }\end{array}$ & 42 & 1978 & Diesel & Euro 0 & 6683 \\
\hline $\begin{array}{l}\text { Mercedes } \\
\text { 0405 }\end{array}$ & 10 & 1989 & Diesel & Euro I & 1225 \\
\hline
\end{tabular}




\begin{tabular}{|l|l|l|l|l|l|}
\hline $\begin{array}{l}\text { Mercedes } \\
\text { 0302T }\end{array}$ & 19 & 1992 & Diesel & Euro I & 1317 \\
\hline $\begin{array}{l}\text { MAN } \\
\text { SL232 }\end{array}$ & 21 & 1998 & Diesel & $\begin{array}{l}\text { Euro } \\
\text { II }\end{array}$ & 1184 \\
\hline $\begin{array}{l}\text { Mercedes } \\
\text { 0345S }\end{array}$ & 6 & 2000 & Diesel & $\begin{array}{l}\text { Euro } \\
\text { II }\end{array}$ & 338 \\
\hline $\begin{array}{l}\text { Mercedes } \\
\text { 0345SC }\end{array}$ & 30 & 2002 & Diesel & $\begin{array}{l}\text { Euro } \\
\text { II }\end{array}$ & 1691 \\
\hline $\begin{array}{l}\text { Mercedes } \\
\text { 0305G }\end{array}$ & 41 & 1978 & Diesel & Euro 0 & 7565 \\
\hline $\begin{array}{l}\text { Mercedes } \\
\text { 0345G }\end{array}$ & 40 & 1998 & Diesel & $\begin{array}{l}\text { Euro } \\
\text { II }\end{array}$ & 6048 \\
\hline
\end{tabular}

Source: The methods described in "The Handbook of Roads and Bridges"

Table 3. Harmful nitrous oxide emissions (NO)

\begin{tabular}{|l|l|l|l|l|l|}
\hline \multicolumn{5}{|c|}{ Calculated } & \multicolumn{2}{c|}{ nitrous } & oxide & \\
\hline & & Year & $\begin{array}{l}\text { Type } \\
\text { of fuel }\end{array}$ & $\begin{array}{l}\text { Euro } \\
\text { stan. }\end{array}$ & $\begin{array}{l}\text { Total } \\
\mathrm{kg} / \\
\text { year }\end{array}$ \\
\hline $\begin{array}{l}\text { MAN } \\
\text { SL200 }\end{array}$ & 3 & 1976 & Diesel & $\begin{array}{l}\text { Euro } \\
0\end{array}$ & 2076 \\
\hline $\begin{array}{l}\text { Mercedes } \\
\text { 0305 }\end{array}$ & 42 & 1978 & Diesel & $\begin{array}{l}\text { Euro } \\
0\end{array}$ & 29059 \\
\hline $\begin{array}{l}\text { Mercedes } \\
\text { 0405 }\end{array}$ & 10 & 1989 & Diesel & $\begin{array}{l}\text { Euro } \\
\text { I }\end{array}$ & 4756 \\
\hline $\begin{array}{l}\text { Mercedes } \\
\text { 0302T }\end{array}$ & 19 & 1992 & Diesel & $\begin{array}{l}\text { Euro } \\
\text { I }\end{array}$ & 6729 \\
\hline $\begin{array}{l}\text { MAN } \\
\text { SL232 }\end{array}$ & 21 & 1998 & Diesel & $\begin{array}{l}\text { Euro } \\
\text { II }\end{array}$ & 6622 \\
\hline $\begin{array}{l}\text { Mercedes } \\
\text { 0345S }\end{array}$ & 6 & 2000 & Diesel & $\begin{array}{l}\text { Euro } \\
\text { II }\end{array}$ & 1896 \\
\hline $\begin{array}{l}\text { Mercedes } \\
\text { 0345SC }\end{array}$ & 30 & 2002 & Diesel & $\begin{array}{l}\text { Euro } \\
\text { II }\end{array}$ & 9481 \\
\hline $\begin{array}{l}\text { Mercedes } \\
\text { 0305G }\end{array}$ & 41 & 1978 & Diesel & $\begin{array}{l}\text { Euro } \\
0\end{array}$ & 43511 \\
\hline $\begin{array}{l}\text { Mercedes } \\
\text { 0345G }\end{array}$ & 40 & 1998 & Diesel & $\begin{array}{l}\text { Euro } \\
\text { II }\end{array}$ & 26732 \\
\hline
\end{tabular}

Source: The methods described in "The Handbook of Roads and Bridges"

"Metropolitan Motor Transport" SJSC also commissions about 15 specialized vehicles designed for emergency service work involving bus fleet maintenance and servicing. These vehicles were manufactured in the 1980s and 1990s; their operating condition is extremely poor, which suggests low effectiveness levels, high maintenance and fuel costs, as well as an extremely deteriorated enterprise image. In that regard, it is crucial that a minimum number of specialized vehicles be purchased to replace the ones currently in use. The increased effectiveness of modern engineering will allow all 15 vehicles to be replaced with two specialized machines and six small motor vehicles which will function as mobile service workshops, doing fast minor repairs on site (i.e. typerelated and other similar activities) without transporting buses to a garage.
As the indicated data shows, the outdated bus fleet and its extremely poor condition lead to high costs and the drastic deterioration of the environment's ecological indicators.

\section{Comparative Characteristic of the Ecological Indicators of Buses}

Buses with diesel engines are the most popular type of buses used in urban transport systems across the world. The constant perfection of the combustion process of their diesel engines and the latest technological solutions have led to a significant reduction in fuel consumption and the achievement of high ecological indicators. Buses with diesel engines still have the best economical indicators, such as purchase prices and costs of operation, compared to other types of buses. In 2014 the Euro VI standard was introduced for all newly manufactured buses, thus reducing the release of more dangerous harmful emissions signigicantly, compared to Euro IV (see table 4). In terms of ecological indicators, buses with so-called "clean" diesel engines practically become equal to certain advanced-guard technology, more specifically buses which run on natural gas (methane). It should be emphasized that buses with diesel engines have a better developed material-technical base with an established maintenance and delivery system, and welltrained personnel. Therefore, this type of buses does not require additional investments [6].

Table 4. Comparison of harmful emissions of Euro IV and Euro VI

\begin{tabular}{|l|l|l|l|}
\hline Indicator & Euro IV & Euro VI & Reduction \\
\hline $\begin{array}{l}\text { Carbon oxide } \\
\text { g/Kwh }\end{array}$ & 1,5 & 1,5 & none \\
\hline $\begin{array}{l}\text { Hydrocarbons } \\
\text { HC } \\
\text { g/Kwh }\end{array}$ & 0,46 & 0,13 & $70 \%$ \\
\hline $\begin{array}{l}\text { Nitrous oxides } \\
\text { NOx, g/Kwh }\end{array}$ & 3,5 & 0,4 & $88,6 \%$ \\
\hline $\begin{array}{l}\text { Particulate } \\
\text { matter PM, } \\
\text { g/Kwh }\end{array}$ & 0,02 & 0,01 & $50 \%$ \\
\hline
\end{tabular}

Source: The National Statistics Institute

Buses which run on natural gas $(\mathrm{CNG})$ are specially designed to operate in an urban environment, given the fact that they have better ecological indicators, compared to buses with diesel engines (see table 5). Their nitrous oxide (NOx) and hydrocarbon (HC) emissions have been reduced the most.

Table 5. Harmful emission of Euro IV and Euro VI

\begin{tabular}{|l|l|l|}
\hline Indicator & Euro IV & Euro VI \\
\hline $\begin{array}{l}\text { Carbon oxide } \\
\text { equivalent, g/km }\end{array}$ & 1000 & $800-850$ \\
\hline $\begin{array}{l}\text { Nitrous oxides } \\
\text { NOx, g/km }\end{array}$ & $1,4-4,5$ & 0,88 \\
\hline
\end{tabular}




\begin{tabular}{|l|l|l|}
\hline $\begin{array}{l}\text { Particulate matter } \\
\text { PM, g/km }\end{array}$ & $0,005-0,03$ & 0,024 \\
\hline
\end{tabular}

Source: The National Statistics Institute

The use of natural gas as fuel for buses in urban transport is considered an advantage, given the fact that natural gas is less expensive and its prices go up more slowly in comparison to diesel fuel.

Buses with hybrid propulsion use two propulsion systems - diesel engines and electric propulsion; they can operate autonomously with either of these systems. Buses with hybrid propulsion have to correspond to the same ecological norms as buses with diesel engines; however, they consume $30-45 \%$ less fuel and therefore their harmful emissions are smaller. Although buses with hybrid propulsion successfully compete with modern diesel engine buses, they are twice as expensive. They store electric energy in powerful storage batteries or ultra-capacitor batteries. One considerable advantage they have is that in both modes of movement, the energy that has been regenerated from stops returns to the electric power source. At low speed and during departure, the control algorithm stipulates only the use of the electric propulsion system, i.e. no harmful emissions are released in these modes. Maintenance costs for hybrid propulsion buses approximate those for diesel engine buses; it should also be taken into account that the batteries of buses that run on them should be replaced at least once during their period of operation [6].

Buses with electric propulsion are the newest trend for urban bus transport. They are considered to be the most environmentally friendly type of buses, and they practically cause no noise pollution. Their propulsion system is entirely electric, with the necessary energy being stored in rechargeable batteries or ultra-capacitor batteries to ensure a short run (80-100 km). New electric buses are twice as expensive as buses with diesel engines, with a 10-year forecast period of operation. Presently, replacement batteries are also quite expensive.

Electric buses consume an average of $1,91 \mathrm{Kwh} / \mathrm{km}$ of energy in 2012, with plans to reduce it to $1,68 \mathrm{Kwh} / \mathrm{km}$ in 2030. By themselves, electric buses are environmentally clean; in actuality, however, they move the release of harmful emissions to the production of electric energy. Regardless of the low energy consumption, the total quantity of electric energy in a large fleet of electric buses will be significant. With Bulgaria's existing energy mix, where over $40 \%$ of the electric energy is generated by thermo-electric power plants, the generation of $1 \mathrm{MWh}$ releases $500-600 \mathrm{~kg}$ of $\mathrm{CO}_{2}$. Electric buses require an appropriate infrastructure in order to operate. Such an endeavor would require significant investments since charging stations need to be built on both ends of each line and in each respective park. In addition to financial resources, the capabilities of the power grid will also have to be guaranteed [6].

The situation is the same, maybe even more serious, with buses that run on hydrogen, given the fact that hydrogen technology for transport needs has not reached the stage of practical application yet.

In conclusion, a qualitative comparison of the possibilities for using the aforementioned bus types in urban transport can be made (see table 6).

Table 6. Comparison of the possibilities for using the aforementioned bus types

\begin{tabular}{|c|c|c|c|c|}
\hline \multirow{2}{*}{ Indicator } & \multicolumn{4}{|c|}{ Bus type } \\
\hline & Diesel & $\begin{array}{l}\text { Natural } \\
\text { gas }\end{array}$ & Hybrid & $\begin{array}{l}\text { Elec- } \\
\text { tric }\end{array}$ \\
\hline $\begin{array}{l}\text { Value of } \\
\text { new buses }\end{array}$ & 1 & $1,2-1,3$ & $1,6-1,9$ & $\begin{array}{l}2,0- \\
2,5\end{array}$ \\
\hline $\begin{array}{l}\text { Ecologi-cal } \\
\text { indicators }\end{array}$ & 1 & 0,9 & $\begin{array}{l}0,6- \\
0,7\end{array}$ & 0 \\
\hline $\begin{array}{l}\text { Energy } \\
\text { costs } \\
\text { BGN/km }\end{array}$ & 1 & 0,7 & 0,6 & 0,2 \\
\hline $\begin{array}{l}\text { Main- } \\
\text { tenance } \\
\text { costs }\end{array}$ & 1 & 1 & 1,2 & $\begin{array}{l}\text { No } \\
\text { data }\end{array}$ \\
\hline $\begin{array}{l}\text { Infrast- } \\
\text { ructure }\end{array}$ & Yes & Yes & $\begin{array}{l}\text { Further } \\
\text { constru } \\
\text { ction } \\
\text { pend. }\end{array}$ & $\begin{array}{l}\text { Const } \\
\text { of a } \\
\text { new } \\
\text { one } \\
\text { pend. }\end{array}$ \\
\hline $\begin{array}{l}\text { Maintenanc } \\
\text { e base }\end{array}$ & Yes & Yes & Partial & None \\
\hline
\end{tabular}

Source: The National Statistics Institute

The individual indicators have been compared in relative units, in relation to the respective indicators of diesel engine buses.

\section{Inferences}

The analysis of the mobile situation in the capital shows that a large percentage of citizens use bus transport. Unfortunately, this type of public transport and personal vehicles are the major cause of air pollution. It should also be taken into account that about $55 \%$ of Sofia's bus fleet is over 12 years old, which suggests constant repair expenses - both current and capital, as well the necessity to maintain a larger number of spare buses. The condition of the obsolete rolling stock is extremely unsatisfactory, and most of the vehicles have not been adapted to the ecological and social standards. On the whole, an extremely unsatisfactory quality can be ascertained for Sofia's public bus transport, as well as deteriorated qualitative freight indicators, i.e. travel time, vehicle safety, vehicle accessibility for disadvantaged people, awareness, comfort during travel, and harmful influence on the environment. This puts the necessity to adopt urgent measures for improving its operational and ecological indicators and the quality of its transport services on the agenda. 


\section{Guidelines for the Stable Development of Public Bus Transport}

The fastest and most radical way to reduce harmful emissions from bus transport in Sofia is to commission new buses with better ecological indicators based on new or perfected technological solutions [7]. It should be taken into account, however, that new technology is more expensive, which could increase operating costs and necessitate the further construction of the existing infrastructure or the creation of an entirely new one. So far the real possibilities for commissioning new environmentally friendly buses include: buses with diesel engines; buses which run on natural gas; buses with hybrid propulsion; buses with electric propulsion.

Buses with diesel engines - at this stage, the incorporation of new diesel engine buses with improved operational features is quite an acceptable option for the city because it does not require additional investments. One important condition is that there is an already well-developed material-technical base for diesel engine buses with an established maintenance and delivery system and welltrained technical staff.

Buses which run on natural gas - vehicles of this type are a rather good option for bus freights within the capital. Its advantages include a high level of environmental friendliness and cheaper natural gas in comparison to diesel fuel. A new CNG bus costs $20-30 \%$ more than a bus with a diesel engine, with no noticeable trend of reduction. As of 2012, CNG buses consume an average of $5,21 \mathrm{Kwh} / \mathrm{km}$ of energy, which is expected to be reduced to $5,0 \mathrm{Kwh} / \mathrm{km}$ in 2030 . These numbers are the equivalent of 46,9 1/100 km and 45,0 1/100 $\mathrm{km}$ respectively in diesel fuel. On the other hand, natural gas is $35 \%$ cheaper than the equivalent amount of diesel fuel. Plans are underway to reduce the average energy consumption of CNG buses from 3,34 Kwh/km in 2012 to $3,17 \mathrm{Kwh} / \mathrm{km}$ in 2030 . These numbers are the equivalent of $30,09 \mathrm{l} / 100 \mathrm{~km}$ and $28,56 \mathrm{l} / 100 \mathrm{~km}$ respectively in diesel fuel. With one fueling, CNG buses traverse about $350-400 \mathrm{~km}$, whereas diesel engine buses traverse $600-900 \mathrm{~km}$. This type of buses requires additional investments to develop an infrastructure for natural gas fueling. Presently, the most commonly used CNG fueling stations (for fast and slow fueling) are of the supercharged type. Results from some studies show that payment for the value of CNG buses and the respective fueling infrastructure takes 5 to 8 years. With an average period of service of 10-12 years, it turns out that the average annual costs for CNG buses are $14 \%$ lower than the respective costs for buses with diesel engines [7].

Buses with hybrid propulsion are an alternative, but not a sufficiently acceptable one due to the fact that, although the existing material base for their maintenance can be used, additional investments are required for its development and for the training of new technical staff. Additionally, a new maintenance and delivery system needs to be created. The maintenance of buses with hybrid propulsion is almost as expensive as the maintenance of buses with diesel engines; it should also be taken into account that batteries need to be replaced at least once during the period of operation.
Buses with electric propulsion - given the aforementioned characteristics of this type of vehicles, it becomes clear that their commission requires significant financial resources. Given the environmentally friendly nature of this type of transport, it is undoubtedly the best alternative for public freights in an urban environment. At this stage, "Metropolitan Motor Transport" SJSC can only afford to purchase a few units to transport passengers only in the central part of the city, where street traffic and air pollution are at their highest [8].

The gradual renewal of the rolling stock in Sofia's motor pool with environmentally friendly and energy-saving vehicles will undoubtedly lead to better environmental parameters such as: improved air quality, reduced harmful emissions, pollution, noise, greenhouse effect and energy consumption, and an overall improved health status of the population and reduced health expenses. However, in order to improve safety and security and guarantee regular and reliable bus transport in the capital, it is necessary to remove even the smallest prerequisites for the occurrence of traffic accidents, in addition to integrating modern rolling stock. For this purpose, the aforementioned measures for the stable development of bus transport need to become a part of a universal strategy for creating stable urban mobility and ensuring the effective organization and management of the freight process first and foremost. The effective management includes optimal connections and high coordination between the various types of urban transport, as well as the incorporation of Intelligent Transport Systems in the organization and management of urban passenger transport [9]. These systems use information and communication technology to collect and process transport data and aid the decision-making process, as well as the evaluation of the effects of transport projects. All traffic participants can take advantage of them before and during travel. The collected information is used for preliminary optimization of various in nature transport operations from the state sector and the private sector. A part of the ITS systems is used to measure various traffic parameters, drivers' behavior and the state of the environment [10]. Another mandatory condition for guaranteeing stable urban mobility is the development of an automated system for traffic control in the capital which, through integration with the existing system for territorial positioning and control of mass urban transport vehicles and providing information for redirecting or limiting traffic, will ensure a more even distribution of all vehicles along the highway network and, by extension, opportunities for accident-free movement of mass urban transport, and reduction of traffic and traffic accidents. In order to facilitate the access to public transport and bus transport services in particular, the two primary automated information systems need to be integrated in public transport: the system for providing passengers with information about public transport and the innovation system for providing public transport tickets. The main purpose of the strategy for stable urban mobility is to fully satisfy the consumer freight needs of Sofia's citizens, which will in turn attract more people to public transport services [11].

\section{Conclusion}


The main approaches and specific measures for the future stable development of public bus transport have to be entirely in the context of creating stable urban mobility. In relation to urban mobility and the problems concerning urban transport, the EC has presented the Green Paper for Urban Mobility - a global strategy which determines the challenges that European cities face in their pursuit of stable mobility; challenges which involve the necessity for achieving easier mobility in cities, reducing environmental and noise pollution, as well as improving the organization, accessibility, safety and security of urban transport [11].

The stable development of Sofia's public bus transport stipulates the effective and stable growth of its social and economic effectiveness which involves: improving the quality of transport services; increasing the appeal of using bus transport in the capital; reducing its harmful influence on the environment and reducing energy consumption through more effective and more sparing use of energy sources. All of this can be achieved by implementing the aforementioned measures which need to become a part of the plan for stable urban mobility and the program for improving the quality of the air in Sofia.

\section{References}

1. Tzvetkova, S., 2018, "The Stable Development of Public Transport”, XX International Scientific Conference "Management and Stable Development", University of Forestry, 23-25.03.2018, Velingrad;
2. Sofia Municipality's Investment Program Along OP "Regions in Growth";

3. Tzvetkova, S., “Analyzing and Evaluating Sofia's Urban Passenger Transport and Guidelines for Its Development", UNWE's Publishing Complex, Sofia, 2016, pp. 9-12;

4. National Institute of Statistics - official website; Tzvetkova, S., "Guidelines for Improving the Quality of Sofia's Urban Passenger Transport in the Context of Stable Urban Mobility" Ninth International Conference "Ecology and Development", Paris, February 7 2018, pp. 289-290;

5. Operative Program "Regional Development" 2007-2013;

6. Sofia Municipality's Program for the Development of Public Transport 2012-2015;

7. Tzvetkova, S., "Increasing the Social Effectiveness of Public Transport", International Conference "Innovations in Science and Education", Prague, March 22 2017, p. 448;

8. Strategy for improving road and traffic safety in the Sofia region, 2012-2020, pp. 17-19;

9. Strategy for ITS Development as part of Sofia Municipality's Integrated Information System, November, 2010, Sofia.

10. Tzvetkova, S., "Improving the Quality of Passenger Transport in Sofia by Incorporating Intelligent Transport Systems", Journal "Economic and Social Alternatives", UNWE, 2017, Issue 4, pp. 34-37;

11. Center of Urban Mobility - Sofia, https://www.sofiatraffic.bg; 